\section{Genotoxic Risk Identification of Soil Contamination at a Major Industrialized City in Northeast China by a Combination of in Vitro and in Vivo Bioassays}

\author{
RUI-YANG XIAO, ${ }^{\dagger}$ ZIJIAN WANG, $,{ }^{*},+$ \\ CHUN-XIA WANG, ${ }^{\dagger}$ GUO YU, ${ }^{\dagger}$ AND \\ Y O N G- G UAN Z H U \\ State Key Laboratory of Environmental Aquatic Chemistry and \\ China-Australia Joint Laboratory of Soil Environmental \\ Sciences, Research Center for Eco-Environmental Sciences, \\ Chinese Academy of Sciences, P.O. Box 2871, \\ Beijing 100085, People's Republic of China
}

The present study evaluated the genotoxicity of field soils in the Tianjin area, one of the most industrialized contaminated areas in northeast China. The genotoxicity of organic extracts of 41 soils was assayed by an in vitro SOS/ umu bioassay with Salmonella typhimurium TA 1535/pSK 1002. From the 41 soil samples, 11 samples were selected to confirm the genotoxic effect by in vivo single-cell gel electrophoresis (comet assay) using earthworms (Eisenia fetida). The results obtained demonstrated that, in the in vitro assay, genotoxicity expressed as induction ratios (IR) ranged from 1.00 to 4.60 , and in the in vivo assay, the genotoxicity expressed as tail moment (TM) varied from 14.6 to $57.8 \mu \mathrm{m}$. All samples with high genotoxicity assessed by the SOS/umu bioassay possessed significantly high genotoxic effects in the comet assay, and there was a correlation $\left(R^{2}=0.736, p<0.05\right)$ between IR and TM in both bioassays. It is concluded that soils in the Tianjin area were seriously contaminated by organic genotoxicants and higher levels of genotoxic effects existed in soils in the urban area of Tianjin as well as in areas near the coastal towns in the northeast part of the city. It can be concluded that a combination of in vivo and in vitro bioassays as a powerful and efficient genotoxicity-assessing tool could facilitate the assessment of genotoxic risk at a regional scale.

\section{Introduction}

Soil contamination is currently considered as an important factor affecting terrestrial and aquatic environments by complex mixtures of both known and unknown contaminants $(1,2)$. Recently, soil pollution by persistent organic pollutants, such as polycyclic aromatic hydrocarbons (PAHs), hexachlorocyclohexane $(\mathrm{HCH})$, dichlorodiphenyltrichloroethane (DDT), and polychlorinated biphenyls (PCBs), has been highlighted, and this pollution is caused by industrial activities and incomplete combustion in heating plants, motor vehicles, and the use of pesticides $(3,4)$. Particular attention should

* Corresponding author phone: +86-10-62849140; fax: +86-1062849140; e-mail: wangzj@rcees.ac.cn.

† State Key Laboratory of Environmental Aquatic Chemistry.

‡ China-Australia Joint Laboratory of Soil Environmental Sciences. be paid to the ecological risk assessment of soil mutagens and carcinogens due to their potentially detrimental effects on microbial, animal populations, and human health. However, most ecological risk assessments of genotoxicants in complex mixtures are through routine chemical analyses that are difficult and hampered by high costs and timeconsuming processes (5). In addition, in these analyses only known compounds are included, and no account is taken for the biological effects of chemical mixtures (6). For the purpose of an adequate assessment of soil pollution, the use of bioassays to rapidly screen the exposure and to demonstrate potential effects of genotoxicants can provide an ideal means to determine the total genotoxic effects of mixtures. Furthermore, ecological risk assessment by bioassays at a regional scale, which can offer an understanding of the distribution of pollutants and primary ecological risk stressors, has seldom been reported to our knowledge. To screen and identify the toxic substances in soils, biomarkers have become valuable ecotoxicological tools $(7,8)$. An efficient (fast and cost-effective) screening system through an in vitro bioassay to identify the samples of interest and to provide basic information for further analysis and risk evaluation was developed (9). While bacterial or in vitro systems could be used as screening tools to define the intrinsic genotoxicity of environmental samples or substances, definitive ecotoxicological risk assessments should consider the expressed genotoxic activity in ecologically relevant organisms in vivo. These will take into account environmentally realistic routes of exposure, the effects of metabolism, and DNA repair efficiency. Furthermore, some chemicals producing positive responses in the in vitro bioassay have shown negative results when evaluated in vivo $(10,11)$. Little information is available as to the comparison of the genotoxicity of soil organic extracts by in vitro assays and in vivo soil exposure.

The SOS/umu test is one of the short-term genotoxicity tests for detecting DNA damage and is a simple colorimetric assay of the induction of the umuC gene in SOS responses. It has been used for the determination of the genotoxic substances and screening for environmental mutagens and carcinogens (12). Single-cell gel electrophoresis (comet assay), which is a simple, sensitive, and rapid technique for the detection of DNA damage (strand breaks, modified bases, and DNA-DNA and DNA-protein crosslinks), has been widely used to detect DNA damage in cells exposed in vivo to a variety of physical or chemical agents in individual cells (13) and therefore can be useful in studies of genetic toxicology, especially ecogenotoxicology (14).

Ecological risk assessment (ERA) is a process that evaluates the likelihood that adverse ecological effects are occurring or may occur as a result of exposure to one or more stressors (15). ERA can be made on a spatial scale, ranging from several centimeters, several meters, and several kilometers to hundreds of kilometers. ERA on a regional scale, which can provide information on the transport process of pollutants and their adverse influence on ecosystems and humans, can provide effective analysis on pollutants and offer scientific evidence to environmental managers or policy makers for effective risk management.

The aim of this study was therefore to assess the soil genotoxicity from the Tianjin area, using the in vitro SOS/ umu bioassay with Salmonella typhimurium TA 1535/pSK 1002 and the in vivo comet assay with coelomocytes from earthworms (Eisenia fetida), and to compare the two assays as screening and identification tools for environmentally relevant genotoxicants at a regional scale. 


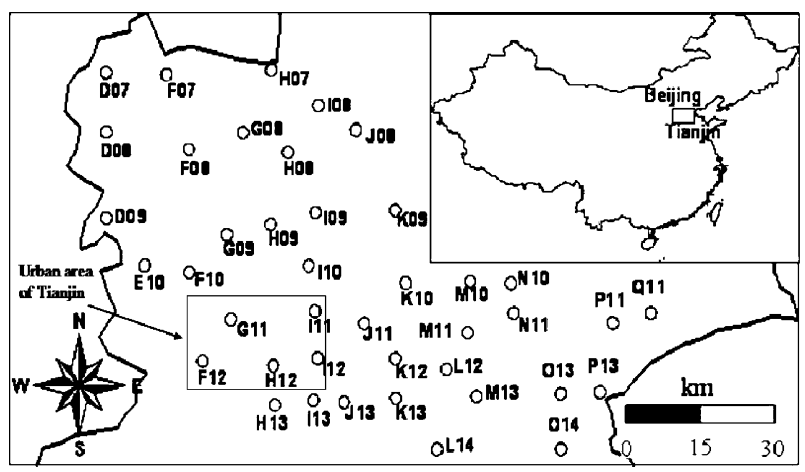

FIGURE 1. Sampling locations in the Tianjin area.

\section{Experimental Section}

Sample Collection and Preparation. Soil samples were collected from the Tianjin area in May of 2001 (Figure 1). Air-dried samples were stored in darkness at $4{ }^{\circ} \mathrm{C}$. The sampling locations were set with relatively uniform distribution using a grid design based on approximately equal longitude and latitude, and they were adjusted by local traffic availability. At each sampling site, five samples (200 g each) were collected from a $100 \times 100 \mathrm{~m}^{2}$ plot at a depth of $10 \mathrm{~cm}$ (located on the crossing diagonals, four in the corners and one in the crossing point) and then thoroughly mixed to form a composite sample (1000 g). One sample was duplicated among 9 sites according to the U. S. Environmental Protection Agency (EPA) sampling strategy. All of the surface soils were collected using acid-cleaned stainless steel scoops and then transferred to precleaned amber glass containers. The $\mathrm{pH}$ values of the 41 samples ranged from 5.2 to 9.0 , and the total organic matter ranged from 0.9 to $3.3 \mathrm{mg} \mathrm{Cg}^{-1}$. All soil samples were sieved ( $1 \mathrm{~mm}$ mesh) and homogenized. After being sieved, $25 \mathrm{~g}$ of an air-dried soil sample was immersed in 200 $\mathrm{mL}(1: 1 \mathrm{v} / \mathrm{v})$ of dichloromethane/acetone for $24 \mathrm{~h}$ and Soxletextracted for $48 \mathrm{~h}$ with a copper sheet to remove sulfur. The solvents were removed by a rotary evaporator (Büchi R-200, Switzerland), and the volume was reduced to $1 \mathrm{~mL}$ under a gentle stream of nitrogen (ultra purity, Tangan, China). The solvents were reduced to $10 \mu \mathrm{L}$, then redissolved with $200 \mu \mathrm{L}$ of dimethyl sulfoxide (DMSO, AMRESCO, USA), and stored in the dark at $4{ }^{\circ} \mathrm{C}$ as a bulk solution. Six concentration levels were used for bioassays, and the concentration sequences were obtained by 2-fold dilution from the bulk solution; however, the final concentration of the exchange solvent, DMSO, in the bioassay was selected as it is not toxic to any cell bioassays.

Study Area. The research area, Tianjin city and its suburbs, lies in northeast China. The total area is approximately 12000 $\mathrm{km}^{2}$, and agriculture is the major land use in the surrounding suburban and rural areas. From the 1960s to the 1980s, large amounts of pesticides were applied in the agricultural areas of Tianjin. In addition, wastewater has commonly been used to irrigate the soil because of the shortage of water (16). Soils from the Tianjin area are contaminated by agricultural runoff and various types of industrial effluents and domestic sewage. Previous work has reported that air, water, and soil were contaminated by persistent organic pollutants such as PAHs and organic chlorinated pesticides $(16,17)$.

SOS/umu Bioassay. The SOS/umu test was carried out according to the method of Oda et al. (18). The test strain Salmonella typhimurium TA1535/PSK1002 was provided by the Osaka Prefectural Institute of Public Health, Japan. In the experiment, the test strain was grown in tryptone glucose ampicillin (TGA) medium overnight at $37^{\circ} \mathrm{C}$. After the incubation period, the optical density $(600 \mathrm{~nm})$ was adjusted to 0.3 by addition of fresh TGA medium. The 96 -well microplate was incubated for $2 \mathrm{~h}$ at $37^{\circ} \mathrm{C}$, and then the optical density $(600 \mathrm{~nm})$ of each microplate well was measured to quantify growth inhibition during the exposure (toxicity assay). The optical density ( 420 and $550 \mathrm{~nm}$ ) was measured after the incubation to determine $\beta$-galactosidase activity. DMSO was taken as a solvent control, and 4-nitroquinoline1-oxide (4-NQO) was taken as a positive control. The samples and solvent blank were tested in triplicate. Data from the measurement were calculated by

$$
A=\frac{1000(B-1.75 C)}{t v D}
$$

where $A$ is the activity of $\beta$-galactosidise, $B$ is the optical density at $420 \mathrm{~nm}, C$ is the optical density at $550 \mathrm{~nm}, D$ is the optical density at $600 \mathrm{~nm}, t$ is the incubation duration (min) of the enzyme reaction, and $v$ is the dilution rate of the bacterial suspension $(\mathrm{mL})$.

To avoid interference, the genotoxicology assessment was quantitatively expressed as induction ratios (IR $=A$ sample/ $\left.A_{\text {solvent blank }}\right)$ under a given amount of soil for extraction. The result is considered to be positive if the IR is higher than 2.0, which means the genotoxic potency of the sample to induce a 2-fold increase relative to that of the solvent blank. IR below 2.0 is scored as non-genotoxic (negative) result.

The genotoxic potency for samples scored as a positive result can also be expressed as soil weight (SW) per well required for the extract to lead to a positive result (IR 2.0). The units of SW are mg per well, and there is a strong relationship between SW and IR $(r=-0.938, p<0.05)$. SW could be obtained from the dose-response relationship shown below

$$
\mathrm{SW}=\frac{V V_{1} W}{5 n V_{2} V_{t}}
$$

where $W$ is the soil weight for Soxlet extraction (25 g), $n$ is the dilution rate at IR $=2.0, V_{t}$ is the bulk solution volume redissolved in $200 \mu \mathrm{L}$ of DMSO, $V$ is the volume of bulk solution for the concentration sequences $(50 \mu \mathrm{L}), V_{1}$ is the volume of culture in the SOS/umu test $(\mu \mathrm{L})$, and $V_{2}$ is the volume of the bulk solution for different concentration sequences.

In general, the IR value depends on the soil amount used for extraction, and a positive result could be obtained by simply increasing the amount of soil. Different IR cannot reflect the relative genotoxic potency of soil samples on the regional scale because the curve slope of the dose-response relationship depends on the characteristics of soil contaminants. In contrary, SW was obtained from the dose-response curve in a similar manner as other toxicological endpoints, such as $\mathrm{LC}_{50}$. Thus, SW can be a more scientifically justified endpoint.

Comet Assay. Earthworms are important organisms in soils, and they appear to be the best organisms for use in soil toxicity evaluation $(19,20)$. The earthworm species Eisenia fetida was selected as the test organism. Healthy earthworms of about 120 days old and weighing about $350 \mathrm{mg}$ with welldeveloped clitellae were used for all experiments. Earthworms were exposed in each soil sample for $72 \mathrm{~h}$. Phosphate-buffered saline (PBS) was used as a negative control, and $100 \mathrm{mg} \mathrm{L}^{-1}$ mitomycin $\mathrm{C}$ as a positive control. After exposure of the earthworms, their coelomocytes were obtained according to the noninvasive extrusion method described by Eyambe et al. (21). The comet assay was conducted following the procedure of Singh et al. (22) with the slight modifications described by Pavlica et al. (23). Approximately 50 cells per slide were examined randomly, and the extent of DNA migration was determined using an image analysis system (Axiovision 4.1, Zeiss, Germany), as only the DNA is visualized using Zeiss Axioplan epifluorescence microscope (Axioskop 
TABLE 1. Statistical Description (Mean, Standard Deviation, and Coefficient Variation) of Results of the Sos/umu Bioassay for the 41 Total Soil Samples and the Comet Assay for a Subset of 11 Soil Samples Selected by Three Levels of Genotoxic Effect: Low, Mediate, and High, Based On the Value of the IR Parameter in the Tianjin Area

\begin{tabular}{|c|c|c|c|}
\hline & \multicolumn{2}{|c|}{ SOS/umu bioassay } & \multirow{2}{*}{$\frac{\text { comet assay }}{\text { tail moment }}$} \\
\hline & induction ratios & soil weight & \\
\hline mean & 2.35 & 10.51 & 36.65 \\
\hline standard deviation & 0.87 & 6.95 & 15.73 \\
\hline coefficient variation & $37.02 \%$ & $66.13 \%$ & $42.90 \%$ \\
\hline
\end{tabular}

2 mot plus, Zeiss, Germany). All steps were conducted in dim light to prevent nonspecific additional DNA breakage. The level of DNA damage in coelomocytes from earthworms is shown as the tail moment. An endpoint "tail moment" (TM) is defined as the product of the tail length and the percentage of DNA in the tail (tail DNA). Cell viability, evaluated by propidium iodide, was consistently above $80 \%$ in all exposed earthworms and above $90 \%$ from the Tanzhe Temple reference site in suburban of Beijing. Viabilities lower than $75 \%$ indicate a cytotoxic effect.

Statistical and Spatial Analyses. The results of bioassays were described by averages and standard deviations from triplicate samples. The statistical program SPSS 11.0 for Windows was used for data analyses. Linear regression and analysis of variance (ANOVA) or a nonparametric KrushalWallis test were performed to investigate the correlation among the variables. The spatial distribution of genotoxic effects in the Tianjin area was generated from the results of 41 discrete sampling locations using kriging interpolation with medium smoothing by Golden Software Surfer v.7.0 (Golden Software, Inc.).

Quality Control for Bioassays. Blanks (chemicals only) were processed separately for all relevant steps of extraction and fractionations as well as for the entire method. All blanks were analyzed in the bioassays and revealed negative results. To avoid the solvent trace influences in the bioassay systems, this critical step was always accompanied by blank experiments.

\section{Results}

The statistical descriptions of results from the two bioassays are listed in Table 1 . The SOS/umu bioassay revealed that the IR value ranged from 1.0 to 4.6 , with an average of 2.4 . The values of 4-NQO as a positive control and DMSO as a solvent control were 3.00 and 1.00, respectively. Figure 2 is the normal distribution of the logarithmically transformed IR values of 41 soil samples. At a given amount of soil for extraction, samples with positive genotoxicity (IR > 2.0) accounted for $53.7 \%$ of all soil samples. The genotoxicities expressed as IR values were higher than those of soil taken from an engineered biopile at the Czechowice-Dziedice Polish oil refinery with a mean value of 0.86 (24). For those soil samples scored as positive, values of SW were between 3.91 and $31.3 \mathrm{mg}$ soil (dry weight (dw)) per well with a mean value of $10.5 \mathrm{mg}$ soil (dw) per well. A comparison of our results with other studies is difficult due to differences in the environmental medium and genotoxicity endpoints.

Figure 3 was plotted according to the values of SW, and this map indicates that soils with the higher levels of genotoxicity were found to be distributed mainly in the urban area of Tianjin as well as in areas near the coastal towns of the Tanggu and Hangu districts northeast of Tianjin. Among the 41 samples, 11 soil samples in the Tianjin area were selected for confirmation using the in vivo comet assay. The selection of subgroups was based on three levels of genotoxic effects, low, medium, and high IR values with means of 1.37,

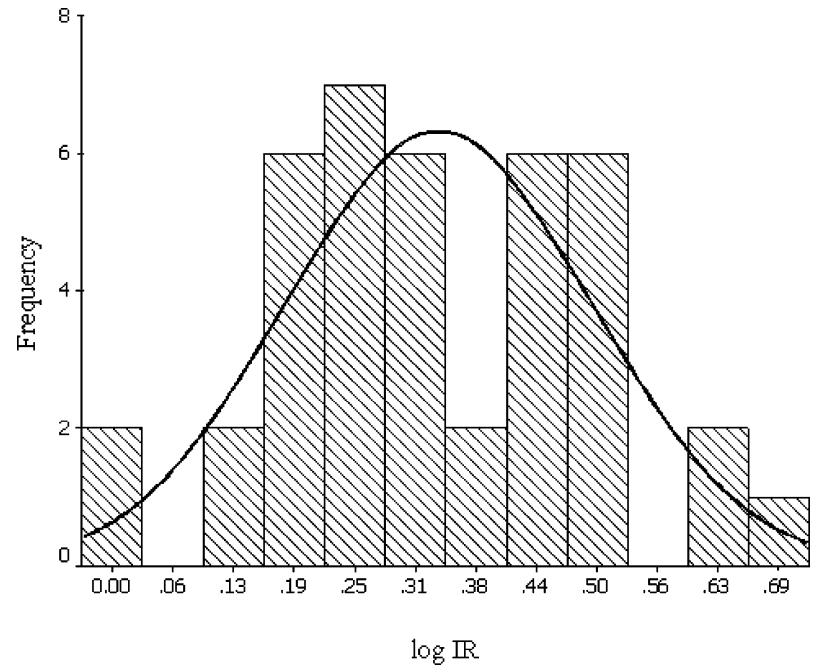

FIGURE 2. Distribution of genotoxic effects expressed as "IR" (logarithmically transformed).

2.02, and 3.46, respectively. Figure 4 shows the summary of results from the comet assay for the 11 samples. TM in these soil samples ranged from 14.6 to $57.8 \mu \mathrm{m}$ with a mean of 36.7 $\mu \mathrm{m}$. Most control cells (PBS) or cells exposed to soil from the reference site did not show any DNA damage or minimal DNA damage, which was the background DNA damage in coelomocytes during the soil exposure. However, exposure to the Tianjin soil samples resulted in increasing levels of DNA damage. There was a significant difference $(p<0.01)$ in TM between earthworms exposed to the Tianjin soils (TM $=36.7 \mu \mathrm{m}$ ) and to the Tanzhe Temple reference soils from suburban of Beijing $(\mathrm{TM}=1.5 \mu \mathrm{m})$. The highest genotoxicity measured by the comet assay was observed in the samples taken from the coastal towns of the Tanggu and Hangu districts on the northeast of Tianjin. Figure 5 demonstrates that the results of both assays showed a good agreement $\left(R^{2}\right.$ $=0.736, p<0.05$ ), indicating the intensity of genotoxicity. Sites with high genotoxicity assessed by the SOS/umu bioassay possessed significantly high genotoxic effects in the comet assay.

The concentrations of the 16 U. S. EPA priority parent PAHs, hexachlorocyclohexane $\Sigma \mathrm{HCH}(\alpha-\mathrm{HCH}, \beta-\mathrm{HCH}$, $\gamma-\mathrm{HCH}$, and $\delta-\mathrm{HCH}$ ), and dichlorodiphenyltrichloroethane $\Sigma \mathrm{DDT}\left(p, p^{\prime}\right.$-DDT, $o, p^{\prime}$-DDT, $p, p^{\prime}$-DDE, $p, p^{\prime}$-DDD, $o, p^{\prime}$-DDE, and $o, p^{\prime}$-DDD) in 41 soil samples are tabulated in Table 2. The concentration of $\Sigma \mathrm{PAH}_{16}$ ranged from 0.20 to $5.19 \mu \mathrm{g} \mathrm{g}^{-1}$ $\mathrm{dw}$ in the study area. The geometric mean of $\Sigma \mathrm{PAH}_{16}$ is 0.85 $\mu \mathrm{g} \mathrm{g}^{-1} \mathrm{dw}$ The greatest concentration of $\Sigma \mathrm{PAH}_{16}$ was detected at location 014 . The geometric means of the concentrations of $\Sigma \mathrm{HCH}$ and $\Sigma \mathrm{DDT}$ in 41 topsoil samples were 17.97 and $10.69 \mathrm{ng} \mathrm{g}^{-1}$, respectively.

\section{Discussion}

In this study, a combination of in vitro SOS/ umu and in vivo earthworm comet bioassays has been applied to investigate the soil genotoxicity at a major industrialized city in northeast China, and the results of the two assays were compared at the same time. The SOS/umu bioassay could be used to detect many types of DNA-damaging agents and is therefore potentially useful for the detection of genotoxicity of complex contaminant mixtures. Moreover, the SOS/umu bioassay provides reproducible results that correlate with measured PAH concentrations. Hamers et al. (25) has applied this method to measure the genotoxicity of diffuse air pollution in The Netherlands and found a quantitative relationship between genotoxicity and the presence of PAHs, indicating that PAHs seemed to be largely responsible for the increased 


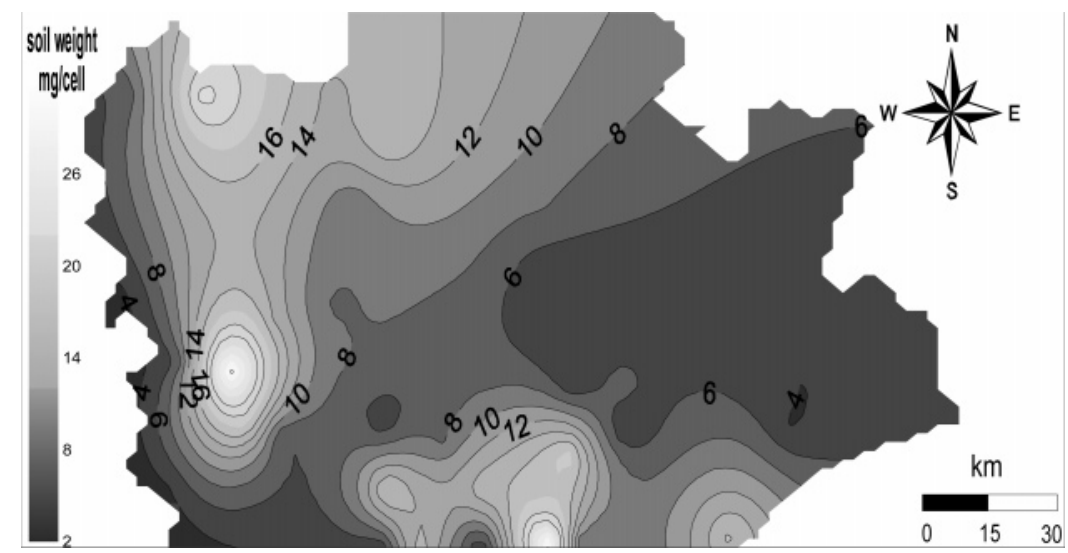

FIGURE 3. Spatial distribution of genotoxic effects of surface soils from the Tianjin area. Reprinted with permission from Xiao, R.; Wang, Z.; Wang, C.; Yu, G. Soil screening for identifying ecological risk stressors using a battery of in vitro cell bioassays. Chemosphere 2006, 64, 71-78. Copyright 2006 Elsevier.

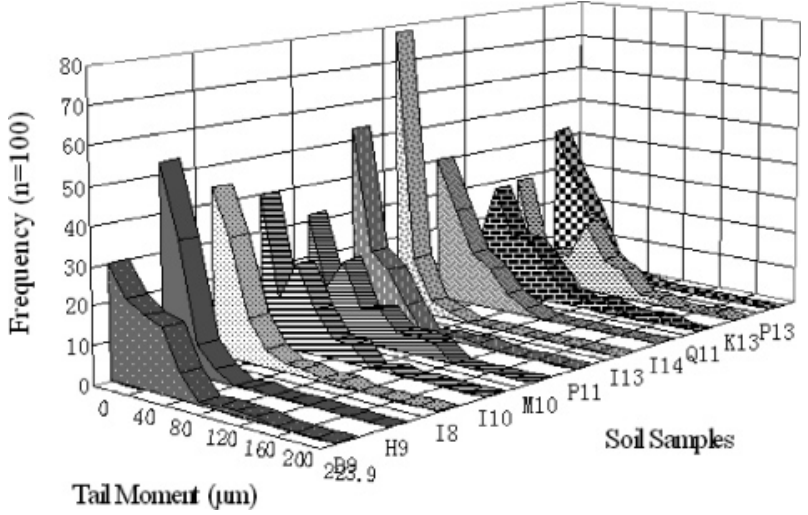

FIGURE 4. Genotoxicity of soil samples from the Tianjin area, as revealed by the comet assay using coelomocytes from earthworms (Eisenia fetida) after $72 \mathrm{~h}$ of exposure, using the parameter of tail moment.

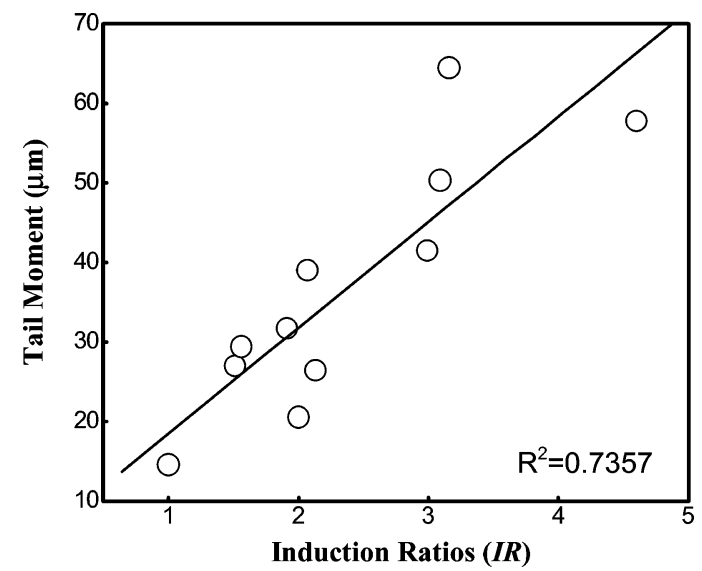

FIGURE 5. Relationship between the in vitro SOS/umu bioassay and the in vivo comet assay $\left(R^{2}=0.736, p<0.05\right)$.

genotoxic activity. In the present study, the relationship between the genotoxicity of 41 soil samples expressed as IR and PAH concentration was investigated. To evaluate the relationship of these two parameters, both were logarithmically transformed for normality (one simple KolmogorovSmirnov test) $(p>0.05)$, and $\log$ IR was used to analyze any relationship with log PAH by nonparametric correlations (Spearman's $\rho$ ). No correlation was found between them for all the samples $(r=0.150, p=0.929, n=41)$; however, if 19 negative soil samples (IR $<2$ ) were weeded out, there was a positive significant correlation coefficient $(r=0.448, p=$
TABLE 2. Concentrations of $\Sigma P A H_{16}\left(\mu \mathrm{g} \mathrm{g}^{-1} \mathrm{dw}\right)$, $\Sigma \mathrm{HCH}(\mathrm{ng}$ $\mathrm{g}^{-1} \mathrm{dw}$ ), and $\sum D D T$ (ng $\mathrm{g}^{-1} \mathrm{dw}$ ) in 41 Topsoil Samples in the Tianjin Área of Northeast China ${ }^{a}$

$\begin{array}{lrrrcrrr}\text { samples } & \text { PAHs } & \mathbf{\Sigma H C H} & \boldsymbol{\Sigma} \text { DDT } & \text { samples } & \text { PAHs } & \mathbf{\Sigma H C H} & \boldsymbol{\Sigma} \text { DDT } \\ \text { D07 } & 0.46 & 27.83 & 4.03 & \mathrm{I} 13 & 3.25 & 18.42 & 1.81 \\ \text { D08 } & 0.45 & 9.16 & 195.92 & \text { J08 } & 0.93 & 25.43 & 61.06 \\ \text { D09 } & 0.23 & 4.47 & 1.38 & \text { J11 } & 3.19 & 17.09 & 3.9 \\ \text { E10 } & 0.38 & 35.83 & 29.08 & \text { J13 } & 0.20 & 1050.41 & 455.41 \\ \text { F07 } & 1.93 & 29.96 & 14.1 & \text { K09 } & 0.44 & 16.62 & 7.34 \\ \text { F08 } & 1.36 & 41.02 & 54.7 & \text { K10 } & 0.62 & 44.38 & 62 \\ \text { F10 } & 0.53 & 5.52 & 0.54 & \text { K12 } & 1.13 & 17.85 & 1.92 \\ \text { F12 } & 0.96 & 12.89 & 19.03 & \text { K13 } & 0.47 & 14.06 & 5.78 \\ \text { G08 } & 0.76 & 11.18 & 36.35 & \text { L12 } & 1.16 & 7.03 & 1.06 \\ \text { G09 } & 0.43 & 5.44 & 0.27 & \text { L14 } & 0.99 & 9.1 & 2.56 \\ \text { G11 } & 2.29 & 51.65 & 5.23 & \text { M10 } & 0.79 & 6.8 & 7.99 \\ \text { H07 } & 0.64 & 6.49 & 2.86 & \text { M11 } & 0.49 & 7.26 & 1.64 \\ \text { H08 } & 0.54 & 3.39 & 16.02 & \text { M13 } & 0.39 & 29.09 & 799.39 \\ \text { H09 } & 0.38 & 3.9 & 36.47 & \text { N10 } & 0.42 & 3.73 & 0.55 \\ \text { H12 } & 0.34 & 7.91 & 6.41 & \text { N11 } & 0.65 & 6.31 & 3.49 \\ \text { H13 } & 4.48 & 7.28 & 6.13 & \text { O13 } & 1.19 & 112.14 & 487.16 \\ \text { I08 } & 1.23 & 5.46 & 8.96 & \text { O14 } & 5.19 & 1078.93 & 102.03 \\ \text { I09 } & 0.23 & 233.84 & 131.98 & \text { P11 } & 0.86 & 3.76 & 0.85 \\ \text { I10 } & 0.61 & 12.49 & 195.58 & \text { P13 } & 2.41 & 25.47 & 11.04 \\ \text { I11 } & 3.14 & 33.54 & 2.77 & \text { O11 } & 3.91 & 49.42 & 2.55 \\ \text { I12 } & 1.09 & 48.32 & 43.57 & & & & \end{array}$

a Data were kindly provided by Dr. S. Tao of Peking University, People's Republic of China.

0.059, $n=22$ ), and no correlation was found between IR and DDT and $\mathrm{HCH}$ concentrations.

The comet assay has been used previously to investigate levels of DNA damage of marine and freshwater animals such as mussels and zebrafish; few studies have been reported for terrestrial environments, especially exposed to earthworms. Chen et al. (26) used the comet assay to assess the genotoxicity of soil samples from wastewater-irrigated areas using coelomocytes from earthworms (Eisenia fetida). After $72 \mathrm{~h}$ of exposure, TM ranged from 9.8 to $41.3 \mu \mathrm{m}$ with an average of $29.8 \mu \mathrm{m}$. These results implicated that the level of genotoxicity in the Tianjin area was probably higher than that from the wastewater-irrigated areas in Beijing. PAHs have been considered as the cause of genotoxic effects in vertebrates or invertebrates with the comet assay $(27,28)$, and it is known that PAHs induce genotoxicity via the production of reactive oxygen species (ROS) from metabolites $(29,30)$, leading to DNA damage either by direct DNA strand breakage or after being metabolized into reactive intermediates that form unstable DNA adducts $(31-33)$. Both processes are likely to trigger DNA excision repair mechanisms that give rise to DNA fragments detectable in the comet assay $(34,35)$.

VOL. 40, NO. 19, 2006 / ENVIRONMENTAL SCIENCE \& TECHNOLOGY $\mathbf{6 1 7 3}$ 
It has been concluded that the high genotoxic risk screened by the in vitro SOS/umu bioassay can be confirmed by the in vivo comet assay. This reflects the similar nature of the two assays. The comet assay detects DNA lesions produced by chemical and physical agents including strand breaks, modified bases, DNA-DNA crosslinks, and DNA-protein crosslinks, and these lesions are primarily repairable, therefore reversible, DNA lesions $(36,37)$. However, the amount of genetic expression detected in the SOS/umu bioassay is subject to DNA repair and therefore does not necessarily result in fixed genetic alterations such as mutations and chromosome aberrations. Moreover, the SOS/umu bioassay is thought to be equally sensitive in assessing genotoxicity as the comet assay. It reacts sensitively to some mutagens and PAHs or other mutagenic compounds in the extracts that should also lead to DNA lesions in the comet assay (38). In addition, a few studies have showed that many kinds of PAHs in the environment are both mutagenic and SOSinducing at the same time. The complexity of the mixtures and mechanisms involved makes the agreement between two assays possible.

Results from this study suggest that a combination of in vivo and in vitro bioassays should be incorporated into a monitoring system, since they are able to detect low-level, chronic, and systematic processes. Both the in vitro SOS/ umu bioassay and the in vivo comet assay using earthworms (Eisenia fetida) have a number of characteristics that make them useful screening models. The SOS/umu bioassay is a suitable choice for screening new and existing chemicals as well as complex environmental samples for unpredicted genotoxicity that may be further identified by chemical analysis. The high sensitivity of the SOS/umu bioassay minimizes the potential for false-negative results. However, false positives may occur primarily due to the fact that an in vitro assay may poorly predict the toxicokinetics of a substance in vivo, and it is more likely that the low reaction of the SOS/umu assay may be ascribed to the presence of compounds that inhibit components of the SOS system or the indicative enzyme, $\beta$-galactosidase. In addition, differential receptor activation and ligand specificity were observed between bacteria and coelomocytes in earthworms, emphasizing the need for heterologous systems for the purposes of risk assessment. For these reasons, the in vivo comet assay can form an excellent complement to the SOS/ umu bioassay.

\section{Acknowledgments}

This work was supported by the National Basic Research Program of China (2003CB415005), the National Natural Science Foundation of China (40471129), and the Chinese Academy of Science (KZCX3-SW-431). We thank Professor Raymond S. H. Yang of Colorado State University for valuable comments and revisions of drafts of this paper. Thanks are also due to Professor S. Tao of Peking University, China, for help in soil sampling.

\section{Literature Cited}

(1) Moore, M. N.; Depledge, M. H.; Readman, J. W.; Paul Leonard, D. R. An integrated biomarker-based strategy for ecotoxicological evaluation of risk in environmental management. Mutat. Res. 2004, 552, 247-268.

(2) Snape, J. R.; Maund, S. J.; Pickford, D. B.; Hutchinson, T. H. Ecotoxicogenomics: The challenge of integrating genomics into aquatic and terrestrial ecotoxicology. Aquat. Toxicol. 2004, 67, 143-154.

(3) Manz, M.; Wenzel, K. D.; Dietze, U.; Schuurmann, G. Persistent organic pollutants in agricultural soils of central Germany. Sci. Total Environ. 2001, 277, 187-198.

(4) Voldner, E. C.; Li, Y.-F. Global usage of selected persistent organochlorines. Sci. Total Environ. 1995, 160-161, 201-210.
(5) Chapman, P. M.; Ho, K. T.; Munns, J. W. R.; Solomon, K.; Weinstein, M. P. Issues in sediment toxicity and ecological risk assessment. Mar. Pollut. Bull. 2002, 44, 271-278.

(6) Citterio, S.; Aina, R.; Labra, M.; Ghiani, A.; Fumagalli, P.; Sgorbati, S.; Santagostino, A. Soil genotoxicity assessment: A new strategy based on biomolecular tools and plant bioindicators. Environ. Sci. Technol. 2002, 36, 2748-2753.

(7) Wells, P. G.; Depledge, M. H.; Butler, J. N.; Manock, J. J.; Knap, A. H. Rapid toxicity assessment and biomonitoring of marine contaminants-Exploiting the potential of rapid biomarker assays and microscale toxicity tests. Mar. Pollut. Bull. 2001, 42, 799-804

(8) Kloepper-Sams, P. J.; Owens, J. W. Environmental biomarkers as indicators of chemical exposure. J. Hazard. Mater. 1993, 35, 283-294.

(9) Giesy, J. P.; Hilscherova, K.; Jones, P. D.; Kannan, K.; Machala, M. Cell bioassays for detection of aryl hydrocarbon (AhR) and estrogen receptor (ER) mediated activity in environmental samples. Mar. Pollut. Bull. 2002, 45, 3-16.

(10) Auletta, A. E.; Dearfield K. L.; Cimino, M. C. Mutagenicity test schemes and guidelines: U. S. EPA office of pollution prevention and toxics and office of pesticide programs. Environ. Mol. Mutagen. 1993, 21, 38-45.

(11) Dearfield, K. L.; Auletta, A. E.; Cimino, M. C.; Moore, M. M. Considerations in the U.S. Environmental Protection Agency's testing approach for mutagenicity. Mutat. Res. 1991, 258, 259283.

(12) Whong, W. Z.; Wen, Y. F.; Stewart, J.; Ong, T. M. Validation of the SOS/Umu test with mutagenic complex mixtures. Mutat. Res. 1986, 175, 139-144.

(13) Fairbairn, J. J.; Khan, M. W.; Ward, K. J.; Loveridge, B. W.; Fairbairn, D. W.; O'Neill, K. L. Induction of apoptotic cell DNA fragmentation in human cells after treatment with hyperthermia. Cancer Lett. 1995, 89, 183-188.

(14) Fairbairn, D. W.; Olive, P. L.; O'Neill, K. L. The comet assay: A comprehensive review. Mutat. Res. 1995, 339, 37-59.

(15) U.S. Environmental Protection Agency. Risk Assessment Forum; EPA/630/R-692/001; Environmental Protection Agency: Washington, DC, 1992.

(16) Tianjin Environmental Protection Bureau. Environmental Quality Statement (1986-1990); Tianjin Environmental Protection Bureau: Tianjin, China, 1996 (in Chinese).

(17) Tianjin Environmental Protection Bureau. Environmental Quality Statement (1996-2000); Tianjin Environmental Protection Bureau: Tianjin, China, 2001 (in Chinese).

(18) Oda, Y.; Yamazaki, H.; Watanabe, M.; Nohmi, T.; Shimada, T. Development of high sensitive umu test system: Rapid detection of genotoxicity of promutagenic aromatic amines by Salmonella typhimurium strain NM2009 possessing high O-acetyltransferase activity. Mutat. Res. 1995, 334, 145-156.

(19) Abdul Rida, A. M.; Bouche, M. B. Earthworm toxicology: From acute to chronic tests. Soil Biol. Biochem. 1997, 29, 699-703.

(20) Bouche, M. B.; Al-Addan, F. Earthworms, water infiltration and soil stability: some new assessments. Soil Biol. Biochem. 1997, 29, $441-452$

(21) Eyambe, G. S.; Goven, A. J.; Fitzpatrick, L. C.; Venables, B. J.; Cooper, E. L. A non-invasive technique for sequential collection of earthworm (Lumbricus terrestris) leukocytes during subchronic immunotoxicity studies. Lab. Anim. 1991, 25, 61-67.

(22) Singh, N. P.; McCoy, M. T.; Tice, R. R.; Schneider, E. L. A simple technique for quantitation of low levels of DNA damage in individual cells. Exp. Cell Res. 1988, 175, 184-191.

(23) Pavlica, M.; Klobucar, G. I. V.; Mojas, N.; Erben, R.; Papes, D. Detection of DNA damage in haemocytes of zebra mussel using comet assay. Mutat. Res. 2001, 490, 209-214.

(24) Plaza, G.; Nalecz-Jawecki, G.; Ulfig, K.; Brigmon, R. L. Assessment of genotoxic activity of petroleum hydrocarbon-bioremediated soil. Ecotoxicol. Environ. Saf. 2005, 62, 415-420.

(25) Hamers, T.; van Schaardenburg, M. D.; Felzel, E. C.; Murk, A. J.; Koeman, J. H. The application of reporter gene assays for the determination of the toxic potency of diffuse air pollution. Sci. Total Environ. 2000, 262, 159-174.

(26) Chen, Y. Ph.D. Dissertation, State Key Laboratory of Environmental Aquatic Chemistry, Research Center for Eco-Environmental Sciences, Chinese Academy of Sciences, 2005.

(27) Kammann, U.; Riggers, J. C.; Theobald, N.; Steinhart, H. Genotoxic potential of marine sediments from the North Sea. Mutat. Res. 2000, 467, 161-168.

(28) Akcha, F.; Vincent Hubert, F.; Pfhol-Leszkowicz, A. Potential value of the comet assay and DNA adduct measurement in dab (Limanda limanda) for assessment of in situ exposure to genotoxic compounds. Mutat. Res. 2003, 534, 21-32. 
(29) Yu, D.; Berlin, J. A.; Penning, T. M.; Field, J. Reactive oxygen species generated by $\mathrm{PAH} o$-quinones cause change-in-function Mutations in p53. Chem. Res. Toxicol. 2002, 15, 832-842.

(30) Palackal, N. T.; Lee, S. H.; Harvey, R. G.; Blair, I. A.; Penning, T. M. Activation of polycyclic aromatic hydrocarbon trans-dihydrodiol proximate carcinogens by human aldo-keto reductase (AKR1C) enzymes and their functional overexpression in human lung carcinoma (A549) cells. J. Biol. Chem. 2002, 277, 2479924808.

(31) Mitchelmore, C. L.; Chipman, J. K. DNA strand breakage in aquatic organisms and the potential value of the comet assay in environmental monitoring. Mutat. Res. 1998, 399, 135-147.

(32) Nacci, D.; Nelson, S.; Nelson, W.; Jackim, E. Application of the DNA alkaline unwinding assay to detect DNA strand breaks in marine bivalves. Mar. Environ. Res. 1992, 33, 83-100.

(33) Nacci, D. E.; Cayula, S.; Jackim, E. Detection of DNA damage in individual cells from marine organisms using the single cell gel assay. Aquat. Toxicol. 1996, 35, 197-210.

(34) Collins, A. R.; Dobson, V. L.; Duinska, M.; Kennedy, G.; Ttina, R. The comet assay: What can it really tell us? Mutat. Res. 1997, 375, 183-193.

(35) Hartmann, A.; Speit, G. Genotoxic effects of chemicals in the single cell gel (SCG) test with human blood cells in relation to the induction of sister-chromatid exchanges (SCE). Mutat. Res. 1995, 346, 49-56.

(36) Bombail, V.; Aw, D.; Gordon, E.; Batty, J. Application of the comet and micronucleus assays to butterfish (Pholis gunnellus) erythrocytes from the Firth of Forth, Scotland. Chemosphere. 2001, 44, 383-392.

(37) Hartmann, A.; Elhajouji, A.; Kiskinis, E.; Poetter, F.; Martus, H. J.; Fjallman, A.; Frieauff, W.; Suter, W. Use of the alkaline comet assay for industrial genotoxicity screening: comparative investigation with the micronucleus test. Food Chem. Toxicol. 2001, 39, 843-858.

(38) Robbiano, L.; Carrozzino, R.; Puglia, C. P.; Corbu, C.; Brambilla G. Correlation between induction of DNA fragmentation and micronuclei formation in kidney cells from rats and humans and tissue-specific carcinogenic activity. Toxicol. Appl. Pharmacol. 1999, 161, 153-159.

Received for review March 28, 2006. Revised manuscript received June 27, 2006. Accepted July 21, 2006.

ES0607335 